ELORE (ISSN 1456-3010), vol. $18-1 / 2011$.

Julkaisija: Suomen Kansantietouden Tutkijain Seura ry.

[http://www.elore.fi/arkisto/1_11/kirjat_kaski.pdf]

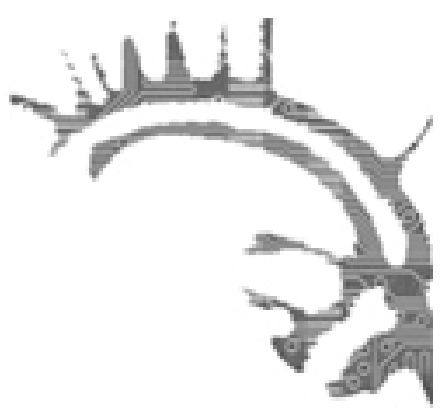

\title{
KIRJA-ARVIO
}

\section{MEISTÄ JA HEISTÄ}

KAINULAINEN, PAULIINA \& SEPÄNMAA, YRJÖ (toim.) 2009: Ihmisten eläinkirja - Muuttuva eläinkulttuuri. Helsinki: Gaudeamus. 235 sivua.

\section{$\underline{\text { Liisa Kaski }}$}

Ihmisen suhde muihin eläimiin ja muiden eläinten oikeus omaan elämäänsä on puhuttanut Suomea kuluneen talven ja kevään ajan. Tv-katsojat ovat joutuneet kohtaamaan sikaloiden ja turkistarhojen todellisuuden parhaaseen katseluaikaan; kasvisruoka herättää poliittisia intohimoja; metsästysrikollisuus ja metsästysoikeuden laillista laajentamista vaativat puheet kovenevat samaan aikaan lajistomme entistä synkemmän uhanalaistumiskehityksen kanssa. Eläinten asiaa ajavien ja heidän vastustajiensa argumentit tuntuvat puhuvan pahasti toistensa ohi. Miten tähän on tultu ja miten ongelmia voitaisiin purkaa?

Itä-Suomen yliopiston ympäristöestetiikan professorin Yrjö Sepänmaan ja pastori Pauliina Kainulaisen toimittama teos Ihmisten eläinkirja - Munttuva eläinkulttuuri perustuu Joensuun avoimen yliopiston ja metsätieteellisen tiedekunnan vuonna 2006 järjestämään Studia generalia -luentosarjaan. Julkaisua on siis ilmeisesti valmisteltu pitkään, ja huolellinen lopputulos kertoo, että välissä kuluneet vuodet eivät ole ainakaan vähentäneet kirjan arvoa ja ajankohtaisuutta. Teos jatkaa hienosti entisessä Joensuun yliopistossa viime vuosina jo perinteeksi muotoutunutta luonnon ja kulttuuri(e)n välisen suhteen tutkimusta.

Eläimiin liittyvä humanistisen alan tutkimus on Suomessa ollut toistaiseksi hajanaista. Eläintutkimus on mielletty lähinnä luonnontieteeksi, joskin eläinoikeusliikkeen aktivoitumisen myötä se on alkanut hivuttautua myös yhteiskuntatieteiden alueelle. Kulttuurintutkimuksen kannalta Ibmisten elänkirjan tärkein edeltäjä ja sisarteos Suomessa on Henni Ilomäen ja Outi Lauhakankaan toimittama Eläin ihmisen mielenmaisemassa vuodelta 2002. Yhdessä nämä kaksi teosta muodostavat läpileikkauksen siitä, mitä suomalaisen eläinkulttuurintutkimuksen saralla on tähän mennessä saatu aikaan. 


\section{ELÄINTEN OIKEUKSISTA JA IHMISEN KULTTUUREISTA}

Ihmisten eläinkirja on jaettu viiteen jaksoon, joissa käsitellään 1) eläinoikeuksia sekä ihmisen ja eläimen suhdetta yleensä Suomen susikysymyksen kautta, 2) kristinuskon ja islamin eläinkuvaa, 3) eläimen ja ihmisen, eläinmäisyyden ja inhimillisyyden rajankäyntiä, 4) tuotantoeläinten oikeuksia sekä 5) eläintä taiteen kohteena ja tekijänä.

Leena Vilkka on eläinoikeusajattelun suomalainen pioneeri, joten on ymmärrettävää, että hänen artikkelinsa "Eläinten oikeudet" avaa Ihmisten elänkirjan. Itse jaan kirjoittajan maailmankatsomuksen ja lukijana nautin kielenkäytöstä, jossa on lupa kysyä yksinkertaisia kysymyksiä moraalista tai vaikkapa rinnastaa toisiinsa eläimen keinosiemennys ja raiskaus. Pidän silti jossain määrin loogisesti ja juridisesti ongelmallisena esimerkiksi eläinten oikenksien käsitettä - vaikka ymmärrän tarkoitusperät, joihin käsitteen käytöllä pyritään - enkä ole täysin vakuuttunut siitä, pureeko Vilkan argumentointi niihin, jotka ovat lähtökohtaisesti toista mieltä eläinten oikeuksista ja arvosta.

Sekä Vilkan että seuraavana vuorossa olevan Outi Ratamäen esimerkkieläimenä on susi. Ratamäen yhteiskuntatieteellisesti orientoitunut artikkeli "Luonto, kulttuuri ja yhteiskunta osana ihmisen ja eläimen suhdetta" on punnittu ja perusteellinen, ja pyrkii myös todella löytämään selityksiä suomalaisen susikysymyksen ongelmallisuuteen. Kahden ensimmäisen artikkelin susiteema olisi ehkä kuitenkin niveltynyt kirjan jatkoon paremmin, mikäli sitä olisi vielä syventänyt joku sutta painavammin kulttuurintutkimuksellisesta näkökulmasta pohtiva puheenvuoro.

Kulttuurintutkimuksen näkökulmasta teoksen antoisimmiksi kirjoituksiksi nousevatkin ne, joissa hahmotetaan uskontoon, taiteeseen ja toisen kohtaamiseen liittyviä teemoja. Uskonnoista käsitellään tällä kertaa kahden suuren maailmanuskonnon, islamin (Teuvo Laitila) ja kristinuskon (Pauliina Kainulainen) suhdetta eläimiin. Molemmissa artikkeleissa on selkeä pyrkimys etsiä uskontoperinteistä nimenomaan eläinmyönteisiä suuntauksia, kokonaan kuitenkaan unohtamatta eläinkielteisyyttä, jota molemmista löytyy etsimättäkin runsaasti. Näkökulma on virkistävä, sillä viime vuosikymmeninä varsinkin kristinusko on luonnonsuojelu- ja eläinasioissa nähty lähinnä negatiivisessa valossa, osin aiheellisesti, mutta useimmiten myös yksioikoisesti ja yksinkertaistaen. On toivoa herättävää ja voimaannuttavaa havaita, että erilaisten eläinkielteisiksi todettujen perinteiden sisältä on aina löydettävissä myös keskenään samankaltaisia elämää puolustavia ajatussuuntia. Kainulaisen artikkelissa erityisen kiitettävää on kyky ylittää myös kristillisen ja esikristillisen ajattelun välinen juopa.

Maria Suutalan artikkeli "Hyvät ja pahat eläimet" jatkaa luontevasti siitä, mihin Kainulaisen ekoteologisesti virittynyt "Eläin jumalan kuvana?" päättyy. Suutala onnistuu lyhyehkössä artikkelissaan hyvin tiivistämään olennaisen länsimaisen luonto- ja eläinsuhteen historiasta, sen vaihtoehdoista kansankulttuurin piirissä sekä uusista ajattelun tavoista, joita ekofeminismiksi nimetty ajatussuunta pyrkii availemaan. Kuten kirjoittaja toteaa, on tarpeen sekä tunnistaa luontosuhdettamme hyvin kauan hallinnut kielteinen ajatteluperintö että luoda uusia ajattelutapoja sen tilalle. Suutalan esimerkit ahvenanmaalaisen kansankulttuurin parista sekä lukuisat muut kirjassa esiin nousevat kansankulttuuri-ilmiöt ja valtauskontojen marginaaleissa eläneet virtaukset osoittavat, ettei tulevaisuutta kohti tarvitse ponnistaa tyhän päältä. 
Liisa Kaski: Meistä ja heistä

Ehkä tärkein ja yksinkertaisin asia, mitä tämä "uusi" ajattelun tapa voisi olla, kiteytyy Seppo Knuuttilan artikkelin otsikkoon "Miltä tuntuu olla joku muu?” Knuuttila pohtii ihmisen universaalia, kaikkina aikoina esiin puskevaa halua ja kykyä miettiä, miltä tuntuu olla jonkun toisen nahoissa. Kuvittelun kyky ja siihen perustuva empatia ovat tapoja ylittää periaatteessa ylittämätön raja minän ja toisen(-lajisen) välillä. Juuri rajankäynti minän ja toisen, esimerkiksi ihmisen ja toisenlajisen eläimen tai naisen ja miehen välillä on tuottanut loputtoman määrän mytologiaa, tabuja ja varoitustarinoita; minän ja toisen raja on niin uteliaisuuden, jatkuvan uudelleenmäärittelyn kuin pelonkin kohde. Kirjoittajalle ominaisella tavalla esimerkit ulottuvat varhaiskantaisesta ja klassisesta mytologiasta nuorempaan tarinaperinteeseen ja populaarikulttuuriin. Rajankäynti on sekä mytologisen että taiteellisen luovuuden lähde. Ajattelun ruokaa, tässä sitä on: osiot kaksi ja kolme ovat Ibmisten eläinkirjan ydin.

Ihmistieteiden käsittäminen laajasti tuo kirjaan sekä epätasaisuutta että hedelmällistä eriäänisyyttä. Erityisesti Taija Kaarlenkasken, Satu Raussin ja Micaela Moreron tekstit peräkkäin luettuina avaavat hyvin kiinnostavan näkymän siihen, miten eri tavoin lehmää ja tuotantoeläinkysymystä voidaan lähestyä perinteentutkimuksen, elintarviketalouden ja eläinsuojelun näkökulmista. Artikkelit myös jossain mär̈in keskustelevat keskenään, ja keskustelu jatkuu lukijan mielessä. Eri kirjoittajien teksteistä koostuvissa kirjoissa tämä ei ole mikään itsestäänselvyys, mutta ansio se on ilman muuta.

\section{Taide vapautTaA}

Kirjan toimittajilla ja useilla kirjoittajista on kannanottoja pelkäämätön ote. Omien lähtökohtien ja asemoitumisen julkituominen on rehellisyyttä lukijaa kohtaan, ja tästäkin syystä Ihmisten eläinkirja on ilo lukea. Silti tarvitaan taiteilija - Ulla Remeksen siteeraama Osmo Rauhala - toteamaan se yksinkertainen asia, että "suhteemme eläimiin ei enää perustu henkiinjäämiseen vaan etiikkaan, meidän on mabdollista valita olla tappamatta eläimiä" (s. 196. kursivointi omani). Taide mitä ilmeisimmin on se inhimillisyyden osa-alue, jossa ihminen on vapaimmillaan, altis ja valmis haastamaan totunnaisuuden, oman itsensä ja kulttuurinsa rajat.

Tähän suuntaan vihjataan jo teoksen johdannossa, jossa Pauliina Kainulainen taideosiota perustellessaan toteaa esteettisen ulottuvuuden muistuttavan "ihmettelyn ja tunteen merkityksestä ihmisen suhteessa eläimiin sekä tunteiden arvomaailmaa muuttavasta voimasta" (s. 11). Olen itse usein todennut saman eläinoikeus- ja ympäristönsuojelutyössä, jossa vastakkainasettelut suojelijoiden ja heidän vastustajiensa välillä tuntuvat kivettyneen paikoilleen: mikään märärä luonnontieteellisiä faktoja (esimerkiksi ilmastonmuutoksesta) tai loogisia argumentteja (esimerkiksi eläinlajien ja -yksilöiden itseisarvosta) ei ilmeisesti riitä muuttamaan ihmisyksilön käytöstä, mikäli tunnereaktio puuttuu. Tunne-elämää rouhiva taide on tässäkin mielessä ihmisyyden elinehto.

Taiteen ja eläimen välisestä suhteesta olisi mielellään lukenut enemmänkin. Ulla Remeksen "Aihe, symboli vai myytti? Eläin suomalaisessa kuvataiteessa" artikkeli on pienistä epätarkkuuksistaan huolimatta tiivis kooste laajasta aiheesta. Kirjan varsinaisista artikkeleista viimeinen, Juhani Pallasmaan "Eläinmaailman mestariarkkitehdit" 
puolestaan on huikaiseva kuvaus maailmoista, joiden olemassaolosta useimmat meistä eivät ole tietoisia. Kuten kirjoittaja toteaa, on todellakin ajatuksia herättävää huomata, että luonto ei noudattele ihmisen käsityksiä eläinlajien "kehittyneisyydestä", ainakaan mitä tulee arkkitehtuurin taitoon: "korkeampina" pitämiemme lajien rakennustaidot ovat yleensä eläinkunnan kehittymättömimpiä, kun taas varsinaiset mestarirakentajat löytyvät meidän näkökulmastamme "alempien" lajien joukosta. Muiden muassa hämähäkkien, lintujen, termiittien ja mehiläisten rakennustaitoa kuvatessaan arkkitehti, professori Pallasmaa tulee nostaneeksi esiin useita sekä yhteiskunnallisesti että kulttuurintutkimuksellisesti relevantteja kysymyksiä ja näkökulmia. Ihmisen käsitys omasta ainutlaatuisuudestaan ja paremmuudestaan eläinlajien joukossa suhteessa vaikkapa evolutiiviseen aikaan, kommunikaatiomme laatuun ja tehoon, ekologiseen sopeutumiskykyyn, siis kykyymme elää toistemme kanssa tässä meille annetussa maailmassa, joutuu kieltämättä viistoon valoon, kun rinnalle asetetaan meidän näkökulmastamme vähäiseltä vaikuttavien olentojen ihmeellisiä taitoja ja elämisen tapoja. Täydellinen sopeutuminen ympäristöön on johtanut monilla meitä "alemmilla" lajeilla paitsi saasteettomiin, jätteettömiin ja luonnonresursseja kestävästi hyödyntäviin, myös teknisesti ja funktionaalisesti ylivertaisiin arkkitehtuuri- ja tekstiilintuotantoratkaisuihin.

Juuri tätä oleellisimmillaan on tiede: tutun ja totunnaisen ylittymistä, ihmislaji- ja minäkeskeisen maailmamme avautumista toista kohden, maailmankaikkeudessa pesivien ilmiöiden näyttämistä niin, että näkemisen jälkeen maailmamme ei enää ole sama. Jokin itsestäänselvyys lakkaa olemasta, jokin perittyjen tapojen ja älyllisen laiskuuden perustalle rakentunut käsitys murtuu. Pallasmaan artikkeli on kirjan helmi. Oivalluksia kaipaavat, lukekaa!

\section{ELÄVIEN YHTEYS}

Yrjö Sepänmaa kokoaa jälkisanoissaan kirjan antia esittämällä muutaman tärkeän kysymyksen. Miten puhua eläimistä, eläinkulttuurista tai ihmisen ja eläimen muuttuvasta suhteesta yleisellä tasolla, kun tosiasiassa ei "ole olemassa eläintä sinänsä, vaan on lajeja ja yksilöitä" ja "(y)leisyyttä tavoitteleva puhe [...] rajoittuukin huomaamatta ihmisen ja nisäkkkään väliseksi" (s. 221. kursiivi omani)? Miten perustelemme ja oikeutamme sen ilmeisen ristiriitaisen logiikan, jonka mukaan "kituvan eläimen lopettaminen on velvollisuus, mutta ibmisen on vaikea tai mahdoton saada kuolinapua niin halutessaan" (s. 222. kursiivi omani)? Miten toimia silloin, kun eläinsuojelu ja luonnonsuojelu näyttävät olevan ristiriidassa keskenään?

Sepänmaa ei varsinaisesti vastaa näihin kysymyksiin, mutta toteaa sen, mitä useat kirjan artikkeleista ovat jo pohjustaneet: "Pitkäaikainen [..] suhde toiseen auttaa ymmärtämään muiden kykyä tuntea kipua, pelkoa, nautintoa tai kiintymystä [..] Syntyy elävien yhteys, tunnesuhde yksilöiden välille, oli parina sitten toinen ihminen, lehmä, hevonen tai kotikissa”. Eikä suhde toiseen rajoitu välttämättä nisäkkäisiin. Voimme havaita myös vaikkapa mehiläisen, kastemadon, varpusen tai ahvenen reagoivan läsnäoloomme ja toimiimme niin, että "syntyy toisilleen etäisten tajuntojen hetkittäinen vuorovaikutus" (s. 224). Perimmäinen yhteenkuuluvuus ja vastavuoroisuus toislajisten kanssa sekä yhteinen riippuvuus meitä kaikkia kannattelevasta Maasta hahmottuvat 
Liisa Kaski: Meistä ja heistä

siksi joksikin, jonka avulla ylitetään niin eläin- ja luonnonsuojelun näennäinen ristiriitaisuus kuin ihmis- ja minäkeskeisen maailmankuvamme tuottama vahinko. Tässä ihmis-, eläin- ja luontosuhteiden uudelleenhahmotustyössä Ihmisten eläinkirja on tärkeä, toivottavasti keskustelua herättävä ja jatkopohdintoihin innoittava puheenvuoro. Erityismaininnan ansaitsee vielä kirjan kansitaide. Esko Männikön valokuvaan hevosen kasvoista kiteytyy kirjan olennainen viesti harvinaisen osuvalla tavalla.

\section{KiRJALLisuUS}

ILOMÄKI, HENNI \& LAUHAKANGAS, OUTI (toim.) 2002: Eläin ihmisen mielenmaisemassa. Suomalaisen Kirjallisuuden Seuran toimituksia 885. Helsinki: SKS.

Filosofian maisteri Liisa Kaski on eläinteemoihin perehtynyt folkloristi. 